\title{
HYDROLOGICAL AND HYDROCHEMICAL CHARACTERISTICS OF LAKE MANYCH-GUDILO WATER ${ }^{1}$
}

\author{
(C) Tatyana B. Filatova, Alexey V. Kleschenkov, \\ Elena G. Aleshina, Vyacheslav G. Soiyer \\ Southern Scientific Center of Russian Academy of Science \\ Rostov-on-Don, Russian Federation \\ fila5784@mail.ru
}

Scientific research works on studying the processes taking place in the Manych reservoirs are aimed not only at obtaining new scientific knowledge, but also assessing the impact of these changes on the species diversity dynamics and the structural and functional organization of communities of hydrobionts and semi-aquatic fauna, as well as developing measures for optimization of water-salt balance, ecological conditions of the Manych Cascade reservoirs bioresources conservation and reproduction. Information on the current mineralization and the ionic composition state of the Proletarian Reservoir waters is important to understand their origin, the possibility of using them for economic purposes, assessing their transformation, and their influence on the environment and biota. It was found that the total mineralization in the surveyed water area in the period of autumn observations remains at a high level (45 g / I), as in 2010 and 2011 . (42.7 and 42.6 respectively). The waters at most stations were attributed to brines, the most western station - to the waters of high salinity. Class of waters is chloride, sodium group, type II. The observed lateral gradient of salinity in the surveyed section of the Proletarian Reservoir is the process of mixing waters with different salinity. The data obtained from expeditionary studies served as the basis for a database on the Proletarian Reservoir (Lake Manych-Gudilo) ecosystem state.

Key words: lake Manych-Gudilo, ecological conditions, water-salt balance, ionic composition, biogenic substances

\section{[Т.Б. Филатова, А.В. Клещенков, Е.Г. Алешина, В.Г. Сойер Гидрологические и гидрохимические характеристики вод озера Маныч-Гудило]}

Научно-исследовательские работы по изучению процессов, происходящих в водоемах системы Маныча, имеют своей целью не только получение новых научных знаний, но и оценку влияния данных изменений на динамику видового разнообразия и структурно-функциональную организацию сообществ гидробионтов и околоводной фауны, а также выработку мер по оптимизации водносолевого баланса, экологических условий сохранения и воспроизводства биоресурсов водохранилищ Манычского каскада. Сведения о современном состоянии минерализации и ионного состава вод Пролетарского водохранилища важны для понимания их происхождения, возможности использования в хозяйственных целях, оценки их трансформации, а также их влияния на среду и биоту. Было установлено, что общая минерализация на обследованной акватории в осенний период наблюдений сохраняется на высоком уровне (45 г/л), как и в 2010 и 2011 гг. (42,7 и 42,6 соответственно). Воды на большинстве станций были отнесены к рассолам, самая западная станция - к водам повышенной солености. Класс вод хлоридный, группа натрия, тип II. В основе наблюдаемого латерального градиента солености на обследованном участке Пролетарского водохранилища лежит процесс смешения вод с разной минерализацией. Полученные данные экспедиционных исследований послужили основой для базы данных по состоянию экосистемы Пролетарского водохранилища (озера Маныч-Гудило).

Ключевые слова: озеро Маныч-Гудило, экологические условия, водно-солевой баланс, ионный состав, биогенные вещества.

\footnotetext{
${ }^{1}$ The publication was prepared within the framework of the implementation of the PFR of the Presidium of the Russian Academy of Sciences I.52 "Ensuring the sustainable development of the South of Russia in conditions of climatic, environmental and technogenic challenges" (SB of the SSC RAS for 2018, project no. AAAA-A18-118011990300-9)".
} 
Tatyana B. Filatova - scientific worker. Southern scientific center of Russian Academy of Science. Rostovon-Don, Russian Federation.

Alexey V. Kleschenkov - candidate of geology, head of the department. Southern scientific center of Russian Academy of Science. Rostov-on-Don, Russian Federation.

Elena G. Aleshina - Federal Research Center of the Southern Scientific Center of the Russian Academy of Sciences. Rostov-on-Don, Russian Federation.

Vyacheslav G. Soiyer - candidate of chemical studies. Federal Research Center of the Southern Scientific Center of the Russian Academy of Sciences. Rostov-on-Don, Russian Federation.

Филатова Татьяна Борисовна - научный сотрудник. Южный научный центр Российской академии наук. Ростов-на-Дону, Россия.

Клещенков Алексей Владимирович - кандидат геологических наук, заведующий отделом. Южный научный центр Российской академии наук. Ростов-на-Дону, Россия.

Алешина Елена Геннадьевна - инженер-исследователь. Федеральный исследовательский центр Южный научный центр Российской академии наук. Ростов-на-Дону, Россия.

Сойер Вячеслав Григорьевич - кандидат химических наук, старший научный сотрудник. Федеральный исследовательский центр Южный научный центр Российской академии наук. Ростов-на-Дону, Россия.

The proletarian reservoir is formed by a dam on the Western Manych River, by flooding and interconnection of a number of lakes in the Manych cavity, including the relict Lake Manych-Gudilo. Above the mouth of the Yegorlyk river is the Novo-Manych dam, dividing the Proletarian reservoir into the western and eastern sections with different salinity regimes: the western part is brackish water, the eastern part is saline. The western compartment can be classified as a high flowing reservoir, while the eastern one, which retains mainly the morphometric characteristics of the Manych-Gudilo Lake, is a region of closed drainage. The proletarian reservoir creates a backwater of highly saline groundwater, which is the reason for the development of salinization of soils at a considerable distance from the coast. The climate in the research area is moderately continental with a moderately cold winter, warm and very warm in summer with a stable manifestation of arid and dry-arid type of weather, the Proletarian Reservoir is located in the steppe arid zone of the south of Russia.

In October 2013, the Institute of Arid Zones of the SSC RAS conducted a hydrohydrochemical survey in the water area between the Barannikovskoy Dam and Lake Manych-Gudilo, one of the main tasks of which was to study the hydrological and hydrochemical characteristics of the waters in the autumn period. Sampling of water was carried out on October 17, 2013 from 10. 35 up to 13 hours. 56 min. according to the approved grid at 7 stations in accordance with the requirements of the Manuals [8]. The composition of the hydrochemical observations included the determination of the active reaction of the medium $(\mathrm{pH})$, the concentration of dissolved oxygen $(\mathrm{CRC})$, determination of the ionic composition, determination of nutrients (ammonium nitrogen, nitrogen nitrites, nitrogen nitrates, phosphate phosphorus and silicic acid). Water samples were taken from the surface horizon using a plastic bucket.

The water temperature and $\mathrm{pH}$ were measured using a portable HANNA pH meter directly on the place. The samples for the determination of the dissolved oxygen concentration were fixed during the selection and subsequent analysis by iodometric titration (Winkler method) on the same day. Analysis of water samples for the purpose of determining the nutrients content was also carried out on the day of sampling in the Hydropower Laboratory of Manych station. Analytical definitions were carried out according to the methods set forth in the Guidelines [6] on the spectrophotometer "Expert003". Samples for the ionic composition were processed in a stationary hydrochemical 
laboratory of the IAZ of the SSC RAS. As a result of fieldwork and data processing, the following results were obtained.

During the survey in the waters of the surveyed water area, the $\mathrm{pH}$ varied within a narrow range $(8.3-8.5)$. By the value of the active reaction of the medium, the water was slightly alkalescent and was characterized by the presence of calcium hydrogen carbonate and magnesium hydrogencarbonate. The water of the Yegorlyk River had a $\mathrm{pH}$ value of 8.8, which indicated the presence of sodium carbonate and sodium hydrogen carbonate and allowed it to be attributed to alkalescent waters. [9]. It is known that the natural waters $\mathrm{pH}$ is determined to some extent by the geology of the catchment basin [13], and the maximum water productivity is between 6.5 and $8.5 \mathrm{pH}$. The waters of the surveyed water area had high oxygen content significantly approaching to $100 \%$ (94 and $98 \%$ saturation) or exceeding $100 \%$, that is, the oxygen regime was favorable for the development of hydrobionts. The oxygen content dissolved in water was observed in the range from $94 \%$ saturation (station No. 3) to $156 \%$ saturation (article No. 15). The waters of the Yegorlyk river $(197 \%)$ were rich in oxygen. High concentrations of dissolved oxygen can be explained by the lowered water temperature at the stations at this time of year, as well as by wind mixing. With a salinity decrease in the water, the concentration of oxygen in it increases, what the results of our observations showed (the KRK increased with the decrease in total mineralization from station No. 2 to station No.18). In addition, significant amount of oxygen may point to the active photosynthesis even in conditions of highly mineralized waters.

During our observations, mineral forms of nitrogen, phosphorus and silicon were detected at a level below the detection limit (as in 2008), which can be explained by a higher rate of these elements consumption by phytoplankton and low rate of their regeneration. In autumn 2009, the content of mineral phosphorus was also at the level of analytical zero, which was apparently caused by the development of algoflora [14]. The content of biogenic elements was considerable in the Egorlyk river: ammonium nitrogen $0.38 \mathrm{mgN} / \mathrm{I}$, nitrogen nitrite $0.43 \mathrm{mgN} / \mathrm{I}$, nitrogen nitrate $3.1 \mathrm{mg} \mathrm{N} / \mathrm{I}$, phosphate 0.54 $\mathrm{mgP} / \mathrm{l}$, silicic acid $-0.38 \mathrm{mgSi} / \mathrm{I}$.

The dynamics of mineralization of water was studied from the sum of the ions to be determined. When moving from west to east, from the station. No 18 to art. No 2, the total mineralization of the waters of the surveyed area gradually increased from $34 \mathrm{~g} / \mathrm{I}$ to $53 \mathrm{~g} /$ $\mathrm{I}$, an average of $45 \mathrm{~g} / \mathrm{l}$. In the Egorlyk river, the total mineralization was $3.61 \mathrm{~g} / \mathrm{I}$ and the waters were characterized as saline. The water of station No. 18 with a total mineralization of $34 \mathrm{~g} / \mathrm{I}$ refers to the waters of increased salinity, and the values of total mineralization $(53,52,44,41,39 \mathrm{~g} / \mathrm{I})$ at stations NoNo. 2-17 allow to attribute these waters to brines [15]. The greater mineralization of water in the eastern part of the surveyed area compared to the western one can be explained by the proximity to the Lake Manych-Gudilo proper with highly mineralized waters, the lithological composition of the rocks that form the catchment area, the coast and the bottom, the mineralization of groundwater, the distribution of salt marsh and alkali soils $[4,5,7]$. The poorly mineralized waters of the Yegorlyk river exert a freshening effect.

In the autumn period, atmospheric precipitation, decrease in the degree of evaporative concentration and an increase in the runoff of rivers, feeding the lake, lead to a regular decrease in the total mineralization of the water compared to summer (in July the average total mineralization was $52.5 \mathrm{~g} / \mathrm{I}$, in October it was equal to $45 \mathrm{~g} / \mathrm{I}$ ). During our research in waters, chlorine anions and sodium-potassium cations dominated, the content of which mainly determined the values of total mineralization, the contribution of sulfates and magnesium was less significant. The tendency toward an increase in the mineralization of Lake Manych-Gudilo and its transition to the class of salt lakes was confirmed in the works $[1,16]$. 
The change in the composition of river and lake water depends on the interaction of a number of natural and anthropogenic factors, including geological features of the terrain (type of soil and rocks), climatic and weather conditions, the type of source of food in the form of surface runoff or groundwater, flow velocity, on ionic and gas composition of biological processes and human economic activity. The cationic and anionic composition of natural waters is determined by the presence of highly soluble minerals in the sedimentary rocks. The graph shows a synchronous increase in the content of chlorine ions, sulfate ions and sodium-potassium ions from west to east from less saline to highly mineralized waters (these ions are characteristic of highly mineralized waters). Generally, for some ions, a certain increase in the concentrations was characteristic, but the concentration of hydrocarbonate ions decreased slightly, which confirms the conclusion [2] that the flowing processes of metamorphic ion composition of the incoming mixture of the river and collector-drainage water in the lake Manych-Gudilo lead to the fact that the average content of hydrocarbonates decreases as the total mineralization of water increases.

In the studied period, the ratio of the concentrations of $\mathrm{Mg} 2+$ and $\mathrm{Ca} 2+$ was 5 , as in 2010. Depending on the concentration, the cations and anions were located in the following sequences: sodium-potassium ions> magnesium ions $>$ calcium ions; ions of chlorine $>$ sulfate ions $>$ hydrocarbonate ions. The examined waters belonged to the chloride class, the sodium group, type II. At the same time, the waters of the Yegorlyk river, which have a desalinating effect, possessed an increased content of sulfate ion with a general low salinity and belonged to the waters of the sulfate-sodium type, and according to the hardness value to the very hard type (more than 20 meq / I) [3], which agrees with the obtained data (23.40 meq / I). When comparing the concentrations of the main ions at the utmost stations, which differ significantly in total mineralization $(34 \mathrm{~g} / \mathrm{I}$ and $53 \mathrm{~g} / \mathrm{I})$, the following was observed: the concentration of chloride, sodium-potassium and calcium ions at the station 2 were almost 2 times higher than at st. 18; the concentrations of magnesium ions and sulfate ions were 1.3-1.4 times higher, the content of hydrocarbonate ions was the same. These differences can be explained by the influence of the hyper-rich Lake Manych-Gudilo in the east and the freshening effect of surface runoff in the west of the surveyed water area. During the sampling and on the eve, the east wind was observed, which could ensure the diffusion of water boundaries with different salinity, a greater supply of water from the eastern side. Perhaps the gradient would be greater in a calm weather. The ion composition of the investigated waters in comparison with the results of previous years and with the waters of the World Ocean is presented in the table 1.

Table 1 - The ion composition of the World Ocean waters, of the examined section of the Proletarian Reservoir and the Manych-Goodilo lake in weight percent of the sum of ions

\begin{tabular}{|c|c|c|c|}
\hline lons & $\begin{array}{c}\text { World Ocean } \\
\text { (according to N.N } \\
\text { Zubov) }\end{array}$ & $\begin{array}{c}\text { Manych-Gudilo lake } \\
\text { (2008) }\end{array}$ & $\begin{array}{c}\text { Proletarian } \\
\text { Reservoir (October } \\
2013)\end{array}$ \\
\hline $\mathrm{Na}^{+}+\mathrm{K}^{+}$ & 31,71 & 27,62 & 25 \\
\hline $\mathrm{Ca}^{2+}$ & 1,16 & 1,22 & 1,4 \\
\hline $\mathrm{Mg}^{2+}$ & 3,69 & 5,73 & 3,2 \\
\hline $\mathrm{Cl}^{\prime}$ & 55,04 & 37,41 & 27,4 \\
\hline $\mathrm{SO}_{4}{ }^{\prime}$ & 7,68 & 27,46 & 0,6 \\
\hline $\mathrm{HCO}_{3}{ }^{\prime}$ & 0,41 & 0,55 & \\
\hline
\end{tabular}


As is known, the salt composition of ocean water is a kind of geochemical constant, and the data obtained by us showed that despite the increase in the salt reserve, the ion composition of water, the ratio of the main ions, remained practically unchanged, which confirms the conclusions of other researchers [14, 17], who studied the dynamics of the water-salt regime of the Manych-Goodilo lake. Comparison of the ionic composition of the waters of the World Ocean and the waters of the water area examined by us, genetically related to sea water, showed that the relative content of chloride and sodium ions is reduced in it and the content of sulfate ion is markedly increased, which is explained by the transforming effect of surface runoff. The content of calcium ions is noticeably lower than that of magnesium ions that is connected with the setting of calcium salts in highly mineralized waters and better solubility of magnesium sulphates and carbonates. The low concentration of the hydrocarbonate ion in the waters of the surveyed section of the Proletarian Reservoir, as in the waters of the World Ocean, is explained by the calcium carbonate.

The results, obtained in the expedition of the IAZ of the SSC RAS in October 2013, basically agree with the data obtained earlier by staff of the IAZ SSC RAS, the SSC RAS and other published data. It was found that the total mineralization in the surveyed water area in the autumn period of observations remains at a high level $(45 \mathrm{~g} / \mathrm{I})$, as in 2010 and 2011. (42.7 and 42.6 respectively). Waters at most stations were attributed to brines, the westernmost station - to the waters of high salinity. Class of waters chloride, sodium group, type II. The observed lateral gradient of salinity in the examined section of the Proletarian Reservoir is the process of mixing waters with different salinity. It is planned to continue research work on studying the processes, taking place in the Manych reservoirs in order not only to obtain new scientific knowledge, but also to assess the impact of these changes on the dynamics of species diversity and the structural and functional organization of communities of hydrobionts and near-water fauna, to develop measures for optimization of the water-salt balance, as well as ecological conditions for the conservation and reproduction of the bioresources of the reservoirs of the Manych cascade. The obtained data of expeditionary studies can also serve as the basis for a database on the Proletarian Reservoir ecosystem state (Lake Manych-Gudilo). It is important at the same time to take into account hydrometeorological and hydrological conditions (for example, wind, runoff, level regime) preceding the survey period.

\section{Лumepamypa}

1. Булышева Н.И. Донные сообщества озера Маныч-Гудило в условиях хронического осолонения // Труды Зоологического института Российской академии наук. СПб., 2013.

2. Кривенцов М.И. Гидрохимия водохранилищ Западного Маныча. Л., 1974.

3. Лурье П.М., Панов В.Д., Саломатин А.М. Река Маныч. Гидрография и сток. СПб., 2001.

4. Матишов Д.Г., Гаргопа Ю.М. Формирование гидролого-гидрохимического режима вод Маныча // Маныч-Чограй: история и современность (предварительные исследования). Ростов-на-Дону, 2005.

5. Матишов Г.Г., Матишов Д.Г., Гаргопа Ю.М. Современный гидрологогидрохимический режим водоемов бассейна р.Маныч. // Доклады Академии наук, 2006. Т.406. № 3. Геохимия.

6. Методы гидрохимических исследований основных биогенных элементов. М., 1988. 
7. Многолетняя изменчивость гидрохимического режима водной системы МанычЧограй / Матишов Д.Г., Орлова Т.А., Гаргопа Ю.М., Павельская Е.В // Водные ресурсы. М., 2007. Т. 34. №5.

8. Наставления гидрометеорологическим станциям и постам. Вып. 9. Л., 1968.

9. Никаноров А.М. Гидрохимия. Л., 1989.

10.РД 52.24.433-2005. Массовая концентрация кремния в поверхностных водах суши. Методика выполнения измерений фотометрическим методом в виде жёлтой формы молибдокремниевой кислоты. Ростов-на-Дону, 2005.

11.РД 52.24.382-2006. Массовая концентрация фосфратов и полифосфатов в водах. Методика выполнения измерений фотометрическим методом. Ростовна-Дону, 2006.

12.Руководство по химическому анализу морских вод РД 52.10.243-92. СПб., 1993.

13.Руководство по химическому анализу поверхностных вод суши / Под ред. А.Д. Семенова. Л., 1977.

14. Сойер В.Г. Особенности гидрохимического режима вод оз. Маныч-Гудило в современный период // Изучение и освоение морских и наземных экосистем в условиях арктического и аридного климата. Материалы международной научной конференции (Ростов-на-Дону, 6-10 июня 2011 г.). Ростов-на-Дону, 2011.

15. Справочник по гидрохимии./ Под ред. А.М. Никанорова. Л., 1988

16. Уланова C.C. Водоемы Кумо-Манычской впадины на территории Калмыкии: режим, экотонные системы побережий и использование // Аридные экосистемы. М., 2011. Т. 17. №2 (47).

17.Фролов А.П. Особенности современного формирования гидрохимического режима оз. Маныч-Гудило // Водный Ресурс. 2000. Т. 27. №3.

\section{References}

1. Bulysheva N.I. Don communities of Lake Manych-Gudilo under conditions of chronic salinity // Proceedings of the Zoological Institute of the Russian Academy of Sciences. SPb., 2013. V. 317.

2. Kriventsov M.I. Hydrochemistry of Western Manich reservoirs. L., 1974.

3. Lurie P.M., Panov V.D., Salomatin A.M. The Manych river. Hydrography and drain. SPb., 2001.

4. Matishov D.G., Gargopa Yu.M. Formation of hydrological-hydrochemical regime of Manych water // Manych-Chogray: history and modernity (preliminary studies). Rostov-on-Don, 2005.

5. Matishov G.G., Matishov D.G., Gargopa Yu.M. The modern hydrologicalhydrochemical regime of the Manych River basin reservoirs. // Reports of the Academy of Sciences, 2006. V. 406. No3. Geochemistry.

6. Methods of hydrochemical studies of basic biogenic elements. M., 1988.

7. The long-term variability of the hydrochemical regime of the water system ManychChogray / Matishov D.G., Orlova T.A., Gargopa Yu.M., Pavelskaya Ye.V. // Water resources. M., 2007. V. 34. No5.

8. Manuals for hydrometeorological stations and posts. No 9. L., 1968.

9. Nikanorov A.M. Hydrochemistry: Textbook. study guide. L., 1989.

10.DD 52.24.433-2005. Silicon mass concentration in the surface. The procedure for performing measurements by the photometric method in the form of a yellow form of molybdosilicic acid. Rostov-on-Don, 2005. 
11.DD 52.24.382-2006. Phosphates and polyphosphates mass concentration in the waters. Measurement technique by photometric method. Rostov-on-Don, 2006.

12. Guidelines for chemical analysis of sea water DD 52.10.243-92. SPB., 1993.

13. Guidelines for chemical analysis of the surface waters/ under the editorship of A.D. Semenov. L.,1977.

14. Soiyer V.G. Features of the hydrochemical regime of the lake Manych-Gudilo waters in the modern period // The study and development of marine and terrestrial ecosystems in arctic and arid climate. Materials of the International Scientific Conference (Rostov-on-Don, 6-10 of June 2011). Rostov-on-Don, 2011.

15. Hydrochemistry guide. L., 1988.

16. Ulanova S.S. The reservoirs of the Kumo-Manych cavity in the territory of Kalmykia: regime, ecotone systems of coasts and using // Arid ecosystems. M., 2011. V. 17. No2 (47).

17. Frolov A.P. Features of the modern formation of the hydrochemical regime of the Manych-Goodilo lake // Water Resourse. 2000. V. 27. No3. 